RGSA - Revista de Gestão Social e Ambiental

ISSN: $1981-982 \mathrm{X}$

Data de submissão: 21/09/2021

Data de aceite: $01 / 12 / 2021$

DOI: https://doi.org/10.24857/rgsa.v15.2786

Organização: Comitê Científico Interinstitucional

Editora Chefe: Eliana Andréa Severo

Avaliação: Double Blind Review pelo SEER/OJS

\title{
SOCIAL-ENVIRONMENTAL CERTIFICATION IN COFFEE PRODUCTION: THE MAKING OF A SUSTAINABLE COFFEE MARKET
}

\author{
Cássio Eduardo Candido Souza ${ }^{1}$ \\ Paulo Henrique Montagnana Vicente Leme ${ }^{2}$ \\ Elisa Reis Guimarães ${ }^{3}$ \\ Gustavo Nunes Maciel $^{4}$
}

\begin{abstract}
Purpose: The aim of this research is to identify the transformations caused by the market practices conducted by UTZ certification program in certified small coffee growers.

Theoretical framework: The Constructivist Market Studies (CMS) explain the economization of goods: interactions in the market generate actions by the actors that will imply how and while goods and services are economized in this same market. Understanding that markets cannot have all of its characteristics described, CMS' focuses on understanding how markets perform, that is, how effective markets are in a given context. These interactions a re caused by market practices performed by actors and market devices.
\end{abstract}

Method/design/approach: documentary research and semi-structured interviews were carried out with 13 certified growers of up to 50 hectares of area in a UTZ certification group coordinated by a private company, with technical a ssistance from a coopera tive from Campos Gera is - MG. Content a nalysis was applied for processing obtained data.

Results and conclusion: both the producers and the certification Management Unit that support them carry out m a rket and structuring practices, so that each one contributes to the formation of this market. The registration processes observed explain the transport of market practices of the same nature between these actors, while the structuring practices make these inscriptions visible in the context of analysis and catalyze the process of assimilation or dissociation from market practices. The results achieved in this research, from the focus on inscriptions, allowed an expansion of the theoretical model of Constructivist Market Studies. It was also possible to highlight the market practices carried out by other authors of the market practices conducted by UTZ, whose interactions were demonst rated through the translation and registration chains.

Research implications: The social contribution of this work was to highlight how the impacts of UTZ certification change the lives of small rural producers through the implementation of sustainable practices, promoting positive transformations in their properties. As for managerial contributions, the observation of the relationship between certification, Management Unit and Producer in the organizational perspective of a certification group stands out, expanding the understanding of the functioning of this certification fulfilment system for the group's performance as a $\mathrm{n}$ independent actor. As a theoretical contribution, this article expanded the systematization of Inscriptions in the process of assimilating Market Practices of the same nature in the context of Constructivist Market Studies.

Originality/value: It was possible to expand the theoretical model of analysis proposed by integrating Inscriptions and coordination relationships as important integrating elements to understand how transformation movements actually occur, building the performativity of an analyzed market.

Keywords: Constructivist Market Studies. Inscriptions. Market Practices. Structuring Practices. UTZ.

\footnotetext{
1 Mestre em Administração pela Universidade Federal de Lavras - UFLA, Minas Gerais (Brasil). Atualmente, coordena o departamento de Normas e Garantias da Rainforest Alliance para a América do Sul. Tem experiência na área de Administração, com ênfase em Agronegócio. Email: cassioecsouza@gmail.com Orcid: https://orcid.org/0000-0002-8935-2680

2 Doutorado em Administração de Empresas pela Universidade Federal de Lavras na área de Marketing, Estratégia e Inovação. Professor no Programa de Pós-Graduação em Administração (PPGA/UFLA), Minas Gerais (Brasil). Email: paulo.leme@ufla.br Orcid: https://orcid.org/0000-0003-4174-5642
}

${ }^{3}$ Doutorado em Administração pela Universidade Federal de Lavras (UFLA), com ênfase em Mercados e Sistemas Agroindustriais. Professora Adjunta do Departamento de Administração e Economia (DAE) da Universidade Federal de Lavras (UFLA), Minas Gerais (Brasil). Email: elisa.rguimaraes@ufla.br Orcid: https://orcid.org/0000-0003-4917-5218

${ }^{4}$ Doutorando em Administração pela Universidade Federal de Lavras (UFLA), Minas Gerais (Brasil) e integrante dos grupos de pesquisa: Núcleo de Estudos em Comportamento Humano nas Organizações. Email: gustavonunesmaciel@yahoo.com.br Orcid: https://orcid.org/0000-0001-5867-3126 


\section{CERTIFICAÇÃO SOCIOAMBIENTAL NA PRODUÇÃO DE CAFÉ: A CONSTRUÇÃO DE UM MERCADO CAFEEIRO SUSTENTÁVEL}

\section{RESUMO}

Objetivo: O objetivo desta pesquisa é identificar as transformações causadas pelas práticas de mercado conduzidas pelo programa de certificação UTZ em pequenos cafeicultores certificados.

Referencial teórico: Os Estudos Construtivistas de Mercado (EMC) explicam a economização de bens: as interações no mercado geram ações dos atores que implicarão em como e enquanto bens e serviços são economizados neste mesmo mercado. Compreendendo que os mercados não podem ter todas as suas características descritas, o foco da EMC em entender como os mercados atuam, ou seja, como os mercados são eficazes em um de terminado contexto. Essas interações são causa das por práticas de mercado realizadas por atores e dispositivos de mercado,

Método: Foram realizadas pesquisas documentais e entrevistas semiestruturadas com 13 produtores certificados de a té 50 hectares de área em um grupo de certificação UTZ coordenado por uma empresa privada, com a ssistência técnica de uma cooperativa de Campos Gerais - MG. A análise de conteúdo foi a plicada para o processamento dos dados obtidos.

Resultados e conclusão: Identificou-se que tanto os produtores quanto a Unidade de Gestão da certificação que os apoia realizam práticas mercadológicas e estruturantes, de forma que cada um contribua para a formação desse mercado. Os processos de registro observados explicam o transporte de práticas de mercado da mesma natureza entre esses atores, enquanto as práticas estruturantes tornam essas inscrições visíveis no contexto de análise e catalisam o processo de assimilação ou dissociação das práticas de mercado. Os resultados alcançados nesta pe squisa a partir do enfoque nas inscrições permitiram uma a mpliação do modelo teórico dos Estudos de Mercado Construtivistas. Ta mbém foi possível destacar as práticas de merca do rea liza das por outros a utores das práticas de mercado conduzidas pela UTZ, cuja s interações foram demonstra das por meio da ca deia de tra dução e registro.

Implicações da pesquisa: A contribuição social deste trabalho foi destacar como os impactos da certificação UTZ mudam a vida de pequenos produtores rurais por meio da implementaçã o de práticas sustentáveis, promovendo transformações positiva s em suas propriedades. Quanto à s contribuições gerencia is, destaca-se a observação da rela çã o entre certificação, Unidade de Gestão e Produtor na perspectiva organizacionalde um grupo de certificação, amplian do o entendimento do funcionamento desse sistema de cumprimento da certificação para a atuação do grupo como ator independente. Como contribuição teórica, este artigo ampliou a sistematização das Inscrições no processo de assimilação de Práticas de Mercado da mesma natureza no contexto dos Estudos de Mercado Construtivistas.

Originalidade/valor: Foi possível ampliar o modelo teórico de análise proposto integrando Inscrições e relações de coordenação como importantes elementos integra dores para entender como os movimentos de transformação realmente ocorrem, construindo a performativida de de um mercado a nalisa do.

Palavras-chave: Estudos de Mercado Construtivistas. Inscrições. Práticas de Mercado. Práticas Estruturantes. UTZ.

\section{INTRODUCTION}

Coffee comprises a dynamic and relevant market, both in financial aspects, as one of the most traded commodities in the world with more than 175 million bags of green coffee produced in 2020 (International Coffee Organization [ICO], 2021); and in social function, since $65 \%$ of the over 280 thousand Brazilian farmers produce coffee in an area of less than 50 hectares (Instituto Brasileiro de Geografia e Estatística [IBGE], 2006).

This dynamic market was shaped by the numerous transformations it faced throughout history, beginning with efforts to standardize coffee, allowing its trading on the Chicago Stock Exchange in the 19th century (Daviron \& Ponte, 2006), until remarkable moments of changes in consumption and commercialization patterns known as 'coffee waves', when new elements were gradually placed in this already complex market (Guimarães, Leme, de Rezende, Pereira, \& dos Santos, 2018). 
One of these elements is sustainability, which became more evident in the context of coffee transactions since the 1980s, when consumers' concern with the origin of production, well-being of coffee farmers and the planet's environmental situation began to play an important role in determining the value of coffee (Kolk, 2011) to final consumers. Since then, those involved in the coffee chain, such as Non-Governmental Organizations (NGO), have come to advocate for these sustainability-related causes (Bennett, 2017).

Currently, certification of agricultural properties has become an expanding business of interest to consumers engaged with sustainability values, and to producers aiming to increase their resilience capacity in several aspects (Formentini \& Taticchi, 2016; Kolk, 2011). The most important proposition of agricultural certification is to improve the performance of sustainability issues such as economic viability, social responsibility and environmental care (Daviron \& Ponte, 2006).

There are examples of internationally recognized sustainability certifications for coffee growing that provide access to markets, such as UTZ, Rainforest Alliance and Fairtrade, and organic certification, which are the most present certifications in the context of Brazilian coffee production (Saes, 2004; Kolk, 2005; Kolk, 2011; Leme, 2015; Bennet, 2017). Although there are differences between them and their regulations, all of them aim to improve the sustainability of coffee production through the implementation of good agricultural and management practices, raising the level of technology and efficiency in rural properties (Kolk, 2011).

UTZ is a relevant player in the coffee market sustainability scenario as it is the largest certification program for the coffee crop in the world. The name UTZ is not an acronym, but a nomenclature originated in Guatemala, where the UTZ certification began its field actions towards the promotion of agricultural sustainability in a holistic approach considering managerial, social and environmental aspects.

Different contemporary theoretical approaches seek to answer questions about how markets are made (Nøjgaard \& Bajde, 2020). Among them, the Constructivist Market Studies (CMS) explain the economization of goods: interactions in the market generate actions by the actors that will imply how and while goods and services are economized in this same market. Understanding that markets cannot have all of its characteristics described, CMS' focus on comprehending how markets perform (Geiger \& Kjellberg, 2021), that is, how effective markets are in a given context. These interactions are caused by market practices performed by actors and market devices (Kjellberg \& Helgesson, 2007).

Considering that sustainability is an important factor in determining whether a coffee exchange can be carried out or not, it is argued that it is valued in this market, and therefore affected by an economization process. The theoretical perspective of CMS analyzes this process, indicating which interactions took place for such a market situation to take effect, revealing how these economization processes occur in the market.

Leme (2015) used CMS to identify and explain how UTZ performed market practices to build the very market in which it operates, coordinating other parts of the coffee production chain, including coffee growers, in this market context. The author observed that UTZ uses several mechanisms, but did not address the effects of these practices in certified growers. Continuing the work of Leme (2015), the following question arises: how do farmers react and are affected by the market practices' interactions performed by UTZ certification in shaping the market of certified coffees?

In this paper, the aim is to identify the transformations caused by the market practices conducted by UTZ identified by Leme (2015) in certified small coffee growers. Two specific objectives assist in this construction: i) To observe how Market Practices interact with each other in the practical context of the producer and, ii) To understand how the market practices performed by UTZ are carried out in the productive context. 
This paper is anchored in the CMS, already pointed out by Leme and Rezende (2018) as an adequate theoretical model to explain market shaping by focusing the actions performed by the actors belonging to this market. It is also shown that the understanding of sustainability and market aspects directed specifically at small coffee growers in Brazil is scarcely represented in academic literature, which this article intends to contribute to by indicating what type of actions small growers develop with their perceptions of the certification.

The theme of socio-environmental certification is relevant in different aspects. First, it is a resource widely used by the industry to address sustainability issues. Second, there is an academic interest in understanding how these certifications translate into impacts within the context of rural properties, although such studies are scarce for the Brazilian reality. Third, in recent decades, in addition to the growing demand for food products with high added value, the search by consumers for food safety criteria has driven the adoption of certification systems by many producers and other suppliers.

The dynamics of the certified coffee market are complex and its actors do not always have well-defined roles. However, there is a variety of studies (Nassar, 2002; Daviron \& Ponte, 2006; Formentini \& Taticchi, 2016; Bennet, 2017; Macgregor, Ramasar \& Nicholas, 2017; Guimarães et al., 2018) which aim to understand how industry and consumer behave in this context. The behaviour of rural producers, however, is insufficiently addressed in scientific literature, representing the research gap to be addressed in this paper.

Therefore, it is expected that with this research it is possible to highlight how the impacts of UTZ certification transform the lives of small rural producers, from the implementation of sustainable practices that promote significant changes in their properties.

In addition, this work is motivated by its possible managerial contribution, as it intends to detail the relationship between Certification, Management Unit and Producer from an organizational perspective of a certification group. Finally, this research intends to bring a theoretical contribution, expanding the discussions on the enrolment process in the assimilation of market practices, within the context of the CMS.

\section{THEORETICAL FRAMEWORK}

\subsection{Constructivist Market Studies (CMS)}

The CMS (Kjellberg \& Liljenberg, 2003) are a field of study that seeks to understand the formation of markets from a perspective that is not only economic but also from the social relations that occur in it (Callon, 1998). Despite being a field of study attributed to a precursor author, it is interesting to observe the range of different authors (Hagberg \& Fuentes, 2018; Hagberg, Kjellberg \& Cochoy, 2019; Geiger \& Kjellberg, 2021) who contribute to the theoretical improvement of the field, making it a rich scenario of complex systematization perspectives. Above all, this field seeks to explain how markets perform, that is, which movements occurred in a given market to make it happen the way it did (Mason, Kjellberg, \& Hagberg, 2015; Geiger \& Kjellberg, 2021).

Two theoretical currents have a great influence in this field of study: i) constructivism, which refers to the philosophical current where reality is built from human social interactions (Janssen \& Van Berkel, 2014) and Bruno Latour's Actor-Network Theory, which addresses the flow of actors in a given context, focusing on identifying the enablers of social networks that make available all the assets that are owned by society, from money to technology (Andrade, 2004)

The Actor-Network Theory assumes the relevance of social interactions between actors as a premise of market construction, however, the 'actor' itself, that is, the driver of an action in this market, is not as relevant under the lens of CMS. The actions performed by market actors are at the center of analysis, and when considering that markets cannot have all their characteristics described (Muniesa, Millo, \& Callon, 2007), CMS place the market construction in the foreground. In other 
words, CMS aim at understanding the formation and practical functioning of markets, considering actors as conductors of processes and not as a structure that houses them, different from the proposal of the Actor-Network-Theory.

In addition to understanding what the actors do in the market context, this field also seeks to understand how goods become tradable. This is the concept of Economization, where to economize a good means pricing it and constructing "circuits of commerce that render things economically commensurable and exchangeable" (Muniesa et al., 2007, p. 3).

Starting from this point in which it is considered that the object of study of the Market Construction Studies is the formation and functioning markets, there are two important guiding principles for this theoretical model. The first of them is multiplicity, meaning that any markets are possible and that the necessary movements for the materialization of that market may or may not occur; and performativity, the process by which these 'ideal markets' are established and become practical and effective versions through actors' behavior (Kjellberg \& Helgesson, 2006). To understand how this conversion occurs, one must consider the three central concepts of CMS: Market Practices, Translation Chains, and Market Arrangements.

Market Practices refer to the activities conducted by the actors in a given market context that give meaning to these actors and put the market in a dynamic movement, that is, in constant transformation (Kjellberg \& Helgesson, 2007). The authors propose three categories of Market Practices: Representational, Normalizing and Exchange Practices. Representational Practices reflect the ideal way of describing the functioning of the market; Normalizing Practices, refer to the guidelines and rules that this market contains to govern its operation; and Exchange Practices involve mechanisms of exchange of economic value in the market (Kjellberg \& Helgesson, 2007).

In the context of Market Practices, there are two other elements: Market Devices, which are objects that interfere in the construction of markets by making actors perform certain actions (Muniesa et al., 2007; Neyland, Ehrenstein, \& Milyaeva, 2019); and Structuring Practices, which do not fit the categorization of Kjellberg and Helgesson (2007) but are relevant in maintaining the market structure now performed (Leme \& Rezende, 2018).

Market Practices also cause reactions and consequences that endow the market with dynamism through constant transformations. These transformations are reflected in Translations, concept originated from the Actor-Network Theory and defined as "an idea, a rule, a text, a product, a technology, a claim [that] spreads over time and space” (Latour, 1986 apud Kjellberg \& Helgesson, 2007, p. 144).

When observing that the different categories of Market Practices interact with each other and that Market Practices of one nature influence those of a different nature, Translation Chains are identified. These Translation Chains result in descriptions, measurement methods, results, rules, tools, and interests, which permeate the market and assist in the creation of new Market Practices (Kjellberg \& Helgesson, 2007). Figure 1 shows how this process occurs from the perspective of CMS. 


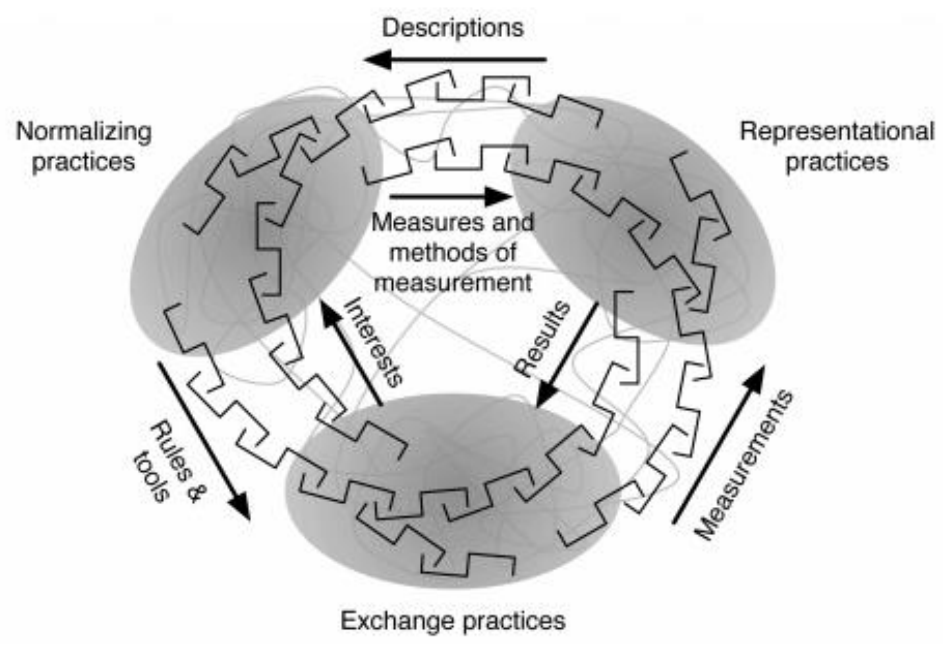

Figure 1. Market Practices and their Translation Chains.

Source: Kjellberg and Helgesson (2007, p. 151).

Finally, the remaining element is the Market Arrangement that relates to the configuration and adjustment of the actors and parties in that market, which allows Market Practices and Translation Chains to be conducted as such (Çaliskan \& Callon, 2010). The Market Arrangement has a temporal characteristic and brings the notion of fit because it derives from the French word agencement, which means 'to organize', and the combination of Structuring and Market Practices, Market Devices, and Actors results in a certain Market Arrangement, making a given market to operate in a certain way (Callon, 2015).

Çaliskan and Callon (2010) list five Market Arrangements: i) Pacifying Goods, where the economized good receives minimum predictable attributes so that it can be traded; ii) Marketizing Agencies, where actors attribute value to this pacified asset; iii) Market Encounters, where the offering party makes this good available to claimants; iv) Price-setting, where the pricing mechanism is negotiated and executed; and v) Market Design, which is the maintenance of this consolidated process.

All of these concepts reinforce that, in this theoretical conception, the market is a dynamic environment in constant transformation. Çaliskan and Callon (2010) name two processes that shape the market as such: Overflows and Framings.

Overflows are imperfections in the Market Arrangement caused by tensions in the arrangement, such as new market practices, the entry of a new actor, a new market device, among others (Çaliskan \& Callon, 2010). If there is an imperfection, the Market Arrangement will seek to stabilize itself, and this is the function of the Framing: the stabilization of the Market Arrangement now under tension, as shown in Figure 2. 

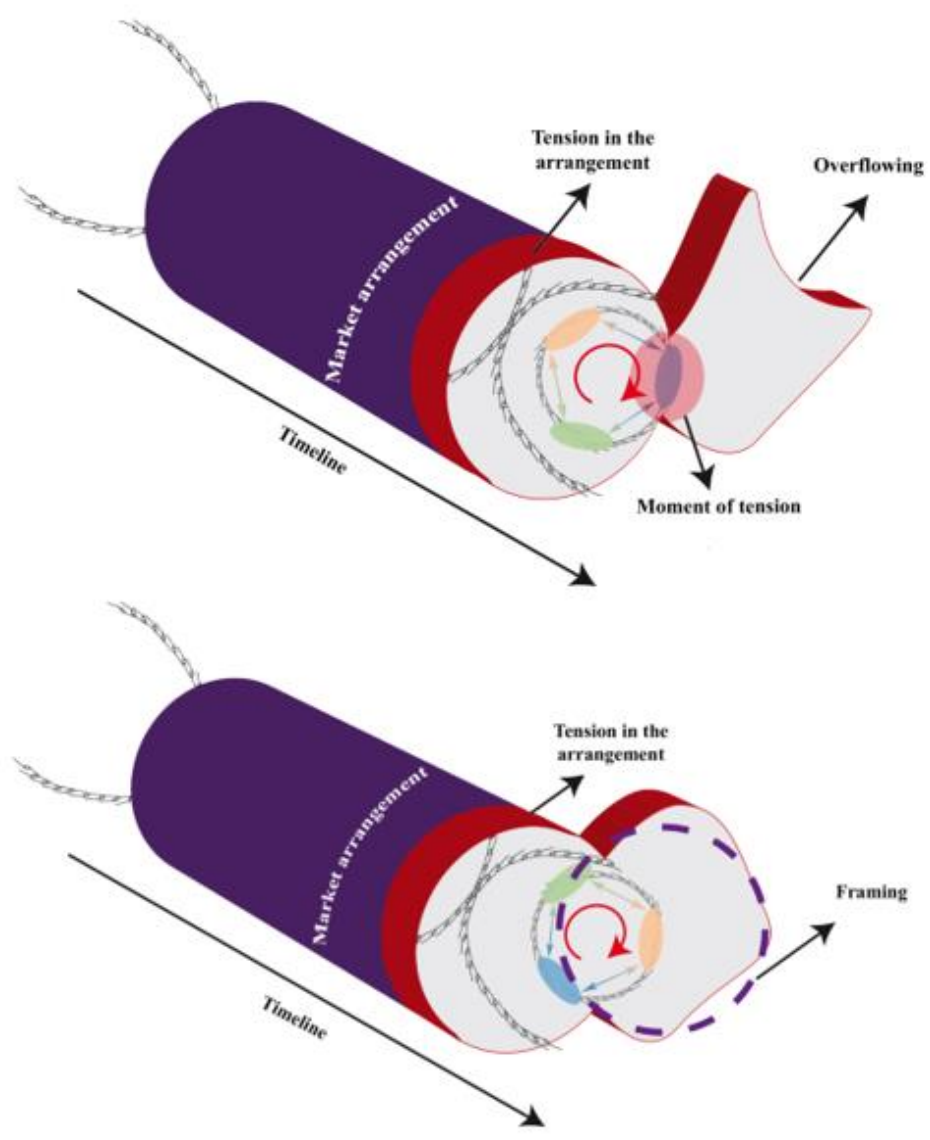

Figure 2. Overflows and Frameworks in the Market Arrangement.

Source: Souza (2019), based on Leme (2015).

The Overflowing-Framing process is what gives dynamism to the market since new Market Arrangements can be formed as a product of this process (Çaliskan \& Callon, 2010), as shown in Figure 3.

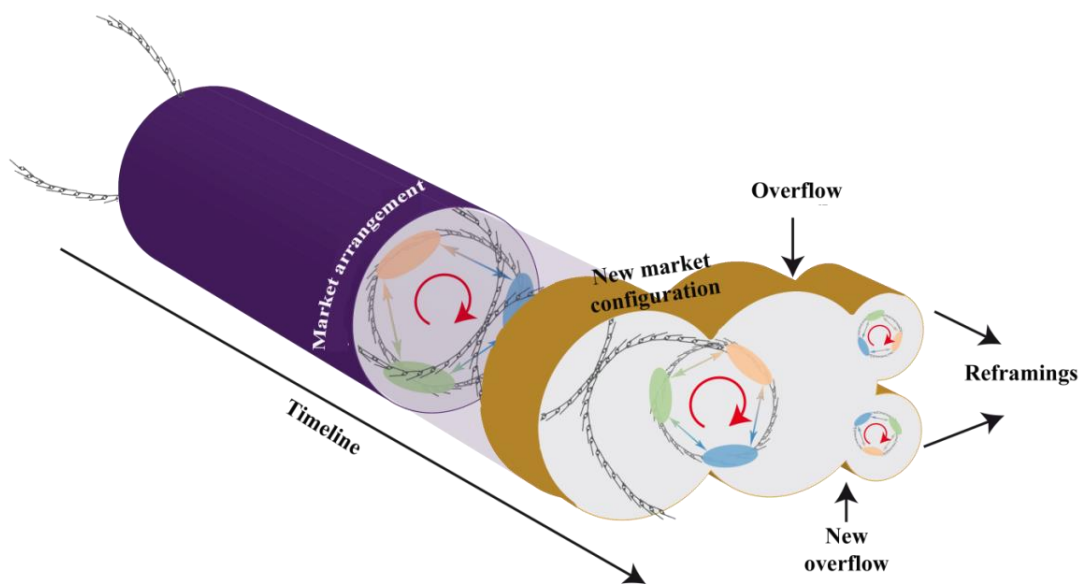

Figure 3. Frameworks in the Market Arrangement.

Source: Souza (2019), ba sed on Leme (2015). 
Table 1 summarizes the central theoretical concepts of CMS, developed by Souza (2019), based on the study regarding the potential use of this theoretical model by Leme and Rezende (2018).

\begin{tabular}{|l|l|l|}
\hline Concept & Definition & References \\
\hline Actor/actant & $\begin{array}{l}\text { Human and non-human actors conducting } \\
\text { marketing practices. }\end{array}$ & $\begin{array}{l}\text { Callon (1986); } \\
\text { Latour(1994); } \\
\text { Miranda (2009). }\end{array}$ \\
\hline Market arrangements & $\begin{array}{l}\text { The product of the adjustment/fitting of the } \\
\text { parties involved in a market allowing a } \\
\text { configuration with a defined purpose. }\end{array}$ & Çaliskan and Callon (2010). \\
\hline Market devices & $\begin{array}{l}\text { Objects elaborated by actors and endowed } \\
\text { with agency that interfere in the construction } \\
\text { of the market, articulating actions, acting or } \\
\text { making others act. }\end{array}$ & $\begin{array}{l}\text { Muniesa et al. (2007); } \\
\text { Cocholiskan (2007); } \\
\text { Çaliskan and Callon (2010). }\end{array}$ \\
\hline Multiplicity & $\begin{array}{l}\text { Assumption that every market is possible to } \\
\text { occur. }\end{array}$ & Kjellberg and Helgesson (2006, 2007). \\
\hline Performativity & $\begin{array}{l}\text { Practical understanding of converting } \\
\text { hypotheticalto practicalmarkets. }\end{array}$ & Kjellberg and Helgesson (2006, 2007); \\
\hline Structuring practice & $\begin{array}{l}\text { Practices that are not normalizing, } \\
\text { representational or exchange that assist in } \\
\text { maintaining a given market arrangement or } \\
\text { in structuring other practices. }\end{array}$ & $\begin{array}{l}\text { Leme (2015); } \\
\text { Leme and Rezende (2016). }\end{array}$ \\
\hline Market practice & $\begin{array}{l}\text { Normalizing, representational or exchanging } \\
\text { practices conducted by interacting actors, } \\
\text { shaping the market. }\end{array}$ & $\begin{array}{l}\text { Callon (1998); } \\
\text { Araújo, Kjellberg and Spencer (2008); } \\
\text { Callon and Muniesa (2005); } \\
\text { Kjellberg and Helgesson (2006, 2007). }\end{array}$ \\
\hline
\end{tabular}

Table 1. Summary of the concepts of CMS.

Source: Souza (2019), ba sed on Leme and Rezende (2018).

Constructivist Market Studies are a theoretical-methodological possibility to point out that it is necessary to establish a new bridge between the detection of the certification effects and a proper measurement of its causes and improvements. It is believed that the practices carried out by UTZ certification can modify the certified producers' practices.

\subsection{The market and operation of certifications}

There are several coffee certifications on the market, with UTZ, Rainforest Alliance and Fairtrade as the main ones operating this business. All of them follow the same purpose of placing minimum sustainability criteria for accomplishment by coffee growers (Reinecke, Manning, \& Von Hagen, 2012), and to connect this sustainably produced coffee with companies and consumers who recognize this value (Daviron \& Ponte, 2006; Kolk, 2011).

Based on the premise of empowering rural producers through the improvement of the activity' economic, social and environmental sustainability, the certifiers create markets and build capacity for the producers who adhere to their programs. This adhesion is conceptually voluntary, although commercial relations between producers and buyers have a strong influence on the decision to join or leave a certification program (Bennett, 2017).

UTZ certification is the certification to be considered in this paper, as it is an integral part of the object of study in this article. It is a Dutch NGO that operates in several coffee producing regions in the world, promoting combined actions to increase performance and sustainable efficiency in the field with demands from interested parties in the market, communicating positive impacts on rural properties and developing communities (UTZ, 2016b).

In order for a producer to apply for UTZ certification, there are two documents to consider: the UTZ Code of Conduct, which places all control points that must be implemented and complied 
with on the rural property (UTZ, 2015), and the Certification Protocol, which indicates all the processes for which a certificate can be granted (UTZ, 2018).

The UTZ Code of Conduct has four blocks that deal with management aspects, good agricultural practices, working and social conditions, and environmental conditions, with one version for properties seeking individual certification and another for a producer group organization. The UTZ Code of Conduct for groups considering the coffee culture has 129 control points that must be implemented in a four-year cycle (UTZ, 2015).

The group certification option requires the establishment of an Internal Management System, that is, a system that is responsible for ensuring that all members of the group are complying with the criteria established in the UTZ Code of Conduct. For the certification to be granted, the properties must undergo an external audit conducted by an entity authorized by UTZ, and as this audit is a sample, such system is also audited to ensure that the farms not sampled comply with the criteria established by UTZ (UTZ, 2018)

UTZ certifies about 14 million coffee bags/year worldwide, over 4 million of which is produced in Brazil in more than 130 thousand hectares (UTZ, 2016a), which represents about $12 \%$ of the global harvest (ICO, 2017). When looking at the coffee market through the lens of CMS, certifications can be considered agents that actively modify the market in which they operate. Leme (2015) carried out this analysis with UTZ Certification and pointed out the various Market Practices that were conducted, meaning that certification can be understood as an actor whose actions cause changes in the market that it helps to build.

From the perspective of the CMS, it can be inferred that, at different times in its history, UTZ conducted practices which modified the market and resulted in overflows. So that these overflows could be assimilated, framings were instituted, resulting in new market arrangements. In addition to the market practices conducted by UTZ, several market devices were used so that the new market arrangement could be maintained as possible.

\section{METHODOLOGY}

This is a qualitative, exploratory-descriptive research developed from a multi-case study, indicated method for investigating "contemporary phenomena within their real-life context specifically when the boundaries between phenomenon and context are not clearly defined" (Yin, 2001, p. 32).

For data collection, documental research was used in the documents and certification profile of the group to understand the certification processes and serve as a guide for the semi-structured interview script (Triviños, 1987). Documental research was used to support the field interviews on two main fronts, the first of which was the analysis of documents relevant to UTZ certification, such as the description of the Code of Conduct and Certification Protocol. Those documents provided guidance on the situation of each of the certified producers and on the general mapping of the group characteristics. In a second moment, the impact reports of private entities and nongovernmental organizations on the UTZ certification and the list of group components and description of the non-conformities identified by the auditors during group scope audits were also analysed. Data were obtained in relation to non-conformities observed in an audit in the period from 2016 to 2018, that comprises the time in which producers were certified from their first year of certification until this work was carried out.

In the interview phase, the study subjects were 13 certified coffee growers of up to 50 hectares of area under a UTZ certification group coordinated by a private company, with technical assistance from a cooperative in Campos Gerais - MG. Thus, the respondents represent each of the 13 properties considered in this work. The interviews were carried out between the end of 2018 and the beginning of 2019, directly on the farms of the sampled producers, which allowed for on-site observations of how the practices are carried out by the producers to maintain the certification. The 
interviews lasted from 45 to 80 minutes each. In addition, these observations generated a field diary with notes, serving as additional sources of contextualization of the interviews carried out with the producers (Creswell, 2010). The material from the transcripts totalled 118 pages. In table 02, the interview script used is displayed. The script was based on documents from the organization included in this research and organized based on different categories of practices, market and structuring (Kjellberg \& Helgesson, 2006; Leme, 2015).

\begin{tabular}{|c|c|c|}
\hline Questions & UTZ Market Practices & Targeted Practices \\
\hline $\begin{array}{l}\text { 1) What is your opinion about the UTZ program? How did he } \\
\text { change the farm in general? }\end{array}$ & $\begin{array}{l}\text { Certification standards and } \\
\text { rules. }\end{array}$ & Norma lizing. \\
\hline 2) How has UTZ changed its view on sustainability? & Philosophy of the program. & Norma lizing. \\
\hline $\begin{array}{l}\text { 3) Have you participated in any review of the UTZ standard? How } \\
\text { was this transition? }\end{array}$ & $\begin{array}{l}\text { Changes in the market when } \\
\text { the Code of Conduct comes } \\
\text { into force. }\end{array}$ & Representational. \\
\hline 4) What is your general perception of UTZ certification? & \multirow{3}{*}{ The governance system. } & \multirow{3}{*}{ Representational. } \\
\hline 5) What is the hardest thing to do to maintain certification? & & \\
\hline $\begin{array}{l}\text { 6) What was the management of the farm/group like before } \\
\text { certification? How was this change and what was it modified? }\end{array}$ & & \\
\hline $\begin{array}{l}\text { 7) How was the sale of coffee before certification? Have there } \\
\text { been any changes? }\end{array}$ & \multirow{2}{*}{$\begin{array}{l}\text { Price formation for UTZ } \\
\text { coffee. }\end{array}$} & \multirow{2}{*}{ Exchange. } \\
\hline $\begin{array}{l}\text { 8) Has there been an increase in the added value of the certified } \\
\text { product? }\end{array}$ & & \\
\hline 9) What is your opinion about the transpa rency of the prize value? & Transparency of transactions. & Exchange. \\
\hline $\begin{array}{l}\text { 10) How has certification changed the relationship with your } \\
\text { cooperative? Did you notice any difference? }\end{array}$ & $\begin{array}{l}\text { Internal control in the market } \\
\text { construction system. }\end{array}$ & Structuring. \\
\hline $\begin{array}{l}\text { 11) How was the farm's a gricultural management in terms of } \\
\text { management, soil, irrigation and harvest? And after certification? }\end{array}$ & \multirow{4}{*}{$\begin{array}{l}\text { Devices for the } \\
\text { dissemination of the } \\
\text { management philosophy. }\end{array}$} & \multirow{4}{*}{ Structuring. } \\
\hline $\begin{array}{l}\text { 12) How was the social management of yourfarm? And with your } \\
\text { employees? }\end{array}$ & & \\
\hline $\begin{array}{l}\text { 13) What was the farm's environmental situation like? Did the } \\
\text { certification change anything? }\end{array}$ & & \\
\hline $\begin{array}{l}\text { 14) What are the biggest benefits, in your opinion, of getting } \\
\text { certified? }\end{array}$ & & \\
\hline $\begin{array}{l}\text { 15) How was the law enforcement on yourfarm? And after } \\
\text { certification? }\end{array}$ & $\begin{array}{l}\text { Hybrid forum building } \\
\text { practices. }\end{array}$ & Structuring. \\
\hline $\begin{array}{l}\text { 16) What is youropinion about the transparency of the UTZ } \\
\text { website? }\end{array}$ & $\begin{array}{l}\text { Construction of the } \\
\text { electronic portalsystem. }\end{array}$ & Structuring. \\
\hline
\end{tabular}

Table 2. Interview script.

Source: The authors.

After recording and transcribing the interviews, the data went through content analysis, where the testimonies of the coffee growers were mapped into keywords, being allocated to initial analytical categories. These initial categories are reduced into intermediate and later final categories, according to the content analysis methodology suggested by Bardin (2011).

\begin{tabular}{|c|c|c|}
\hline Initial Categories & Intermediate Categories & Final Categories \\
\hline UTZ operation (1) & \multirow{3}{*}{$\begin{array}{c}\text { The implementation and maintenance } \\
\text { of the UTZ standard. }\end{array}$} & \multirow{8}{*}{$\begin{array}{l}\text { The normative context of UTZ applied to the } \\
\text { rural reality of small coffee growers. }\end{array}$} \\
\hline Certification Challenges (5) & & \\
\hline Certification Benefits (14) & & \\
\hline Changes in Management (6) & \multirow{5}{*}{ Farm-level certification changes. } & \\
\hline $\begin{array}{l}\text { Changes in agricultural } \\
\text { practices (11) }\end{array}$ & & \\
\hline Social Changes (12) & & \\
\hline EnvironmentalChanges (13) & & \\
\hline $\begin{array}{l}\text { Compliance with legislation } \\
\text { (15) }\end{array}$ & & \\
\hline
\end{tabular}




\begin{tabular}{|c|c|c|}
\hline Sustainability Philosophy (2) & \multirow{2}{*}{$\begin{array}{l}\text { The understanding of UTZ as a } \\
\text { sustainable philosophy. }\end{array}$} & \multirow{4}{*}{$\begin{array}{l}\text { Certification representations in the } \\
\text { production context. }\end{array}$} \\
\hline The UTZ business (4) & & \\
\hline $\begin{array}{l}\text { Representativeness and } \\
\text { participation ( } 3 \text { ) }\end{array}$ & \multirow{2}{*}{$\begin{array}{l}\text { The representation of coffee growers in } \\
\text { the construction of the program. }\end{array}$} & \\
\hline $\begin{array}{l}\text { Relationship with the } \\
\text { certification group (16) }\end{array}$ & & \\
\hline Product sales mechanisms (7) & \multirow{3}{*}{ Certification exchange perspective. } & \multirow{4}{*}{$\begin{array}{c}\text { The practicalexchange environment of } \\
\text { certification accessed by small coffee } \\
\text { growers. }\end{array}$} \\
\hline Adding value (8) & & \\
\hline Added value transparency (9) & & \\
\hline $\begin{array}{l}\text { Relationship with the } \\
\text { cooperative (10) }\end{array}$ & Building relationships via certification. & \\
\hline
\end{tabular}

Table 3. Analytical Categories for Content Analysis.

Source: The authors.

The initial categories represent the 16 questions (Table 3) that made up the applied semistructured interview script; grouped into intermediate categories representing the themes where certification influences within the productive context; grouped into final categories related to the representational, normalizing and exchange aspects. In this paper, only the final categories defined in the scope of the work are indicated, namely: UTZ' normative context applied to the rural reality of small producers; the representations of certification in the productive context, and; the practical transactional environment of certification accessed by small producers.

\section{RESULTS AND DISCUSSION}

This section presents and discusses results on Interaction between UTZ's Market Practices and those of the other observed actors (section 4.1) and the implementation of UTZ Market Practices in the productive context (section 4.2).

\subsection{Interaction between UTZ's Market Practices and those of the other observed actors}

In the observed context, three actors were identified: UTZ, as the certification that represents the seal to which producers are certified; the Management Unit, which represents the system that manages the certification components as required by the certification itself; and the producers that make up the certification group. The fact that there is more than one actor involved is an important attribute of the dynamics of this context. Leme's (2015) work indicated that UTZ carries out Representational Practices identified as [1] the norms and rules of other systems that served as inspiration for this certification and [2] UTZ's philosophy and its transformations. The author identified that the Representational Practices conducted by UTZ changed the way in which other actors perform their Representational Practices.

In the context of the Management Unit, it was observed that there is a [1] centralization of the representation of group members, based on the fact that UTZ itself allows other actors to assume their representation in a productive context, creating bridges of communication between the member demands and certification requirements. Because the philosophical aspect of UTZ permeates its entire Code, it is observed that [2] the Management Unit replaces UTZ as a representative of the certification, which in practice means that if a producer has doubts about the certification process, this producer will not reach for UTZ, but rather to the Managing Unit.

From the producer's point of view, it is observed that the implementation of the certification changes his perceptions of representation of the farm itself, usually making him proud to be a certified member. The vision and the [1] resignification of the farm in a rural enterprise, that is, making it more professional and profitable; and the [2] aesthetic and functional resignification of the farm, indicating a sense of improvement and beauty in the general context, are Representational 
Practices conducted by certified producers in this market. Below, an excerpt from one of the interviewees illustrates the above.

\begin{abstract}
"Professionalization, thus, through knowledge itself, reading, knowledge, courses, production cost courses, for example. From the knowledge of how you identify defects in your crop, pests, incidence of pests, recognize pests. And another thing, extremely important, is the organization, so this organization of both machinery and products, right? And the structure of ownership itself. So, you start to see your property from the point of view of the company, which I think, small producer, as it is familiar, right?" (Interviewee 7).
\end{abstract}

Concerning Normalizing Practices, Leme (2015) points out [1] the new versions of the UTZ Code of Conduct that indicate the certification criteria as a product of their representational transformations over time, and the [2] UTZ' Governance system that deliberates and resolves the normative aspects of field certification.

Bennett (2017) addresses certifiers' governance systems and how producers are involved in them. It was observed that the certification action to establish deliberation committees results in this role's delegation to the Management Unit since it allows the [1] creation of the controlling and operational rules of the group that determine the criteria of entry, exit, rights and duties of the producer members of the group. On the other hand, as the certification changes the versions of its Code of Conduct, the Management Unit also changes the assumptions of [2] provision of technical advice, indicating to its body of implementers what must be done to achieve the compliance of farms. It also influences farmers ability to comply or not with the standard, since during investigations it was identified that in 2015 , the transition year of the last standard, there was a drastic drop in the number of certified producers as part of the group. An example can be seen below.

\footnotetext{
"Before, we didn't do anything with soil, didn't do anything with leaves, right? Today we already do the analysis, poison, defensives, we even throwed without using PPE, protection there, right? Today already use it, already have this greater vision of being more careful. Today, today we no longer throw any product, right? At first, if you say that, any product there, oh that's good, that is, we used to throw without researching, without knowing what you were throwing, today we don't throw anymore." (Interviewee 04).
}

As the Management Unit changes the assumptions for providing technical advice, it also changes the capacity and form related to [1] the implementation of the practices required by UTZ certification by producers, which is directly linked to the permanence of a producer in the group. One of these conditions and rules that the Management Unit places for producers to remain in the group is the monitoring of activities through the [2] field notebook filling, creating a managerial culture among these producers so that they can register the agricultural activities of their properties and providing an input for continuous improvement through the generation of indicators. The following is an excerpt from an interview that illustrates this well.

\footnotetext{
"Ah, the certification today gave us a vision of how to manage a property, having the notes, taking care of the environment, even our own health, right? It helped a lot, for example, today we do blood tests, before we didn't do it, now you know how your blood is, right? We didn't have a water test, now it's already done, so this sense of health has also improved a lot, right?" (Interviewee 04).
}

Considering the Exchange Practices, Leme (2015) points out the [1] price formation of certified coffees and the premium inherent to the certification and [2] transparency practices in the transactions as an integral part of the construction of the UTZ certification market from the perspective of values. The price premium is an exchange condition imposed by certifiers to \begin{tabular}{|l|l|l|l|l|l|l|}
\hline Rev. Gest. Soc. Ambient. & São Paulo (SP) & v.15 & p.01-21 & e02786 & 2021. \\
\hline
\end{tabular} 
remunerate coffee produced sustainably above the market price, while making efforts to communicate these values in the most transparent way throughout the supply chain, through an online traceability system.

Based on the premise that the sustainability of coffee is something economized, that is, it has market value, the Management Unit uses the certification group as a value proposition within an [1] internal institutional program related to sustainability where the entry of producers in the certification group is based on the institutional/commercial relationship with the Management Unit. This commercial relationship so that a producer can remain in the group occurs from the exchange of part of his agricultural production for necessary inputs for the cultural treatment of crops (an operation known as barter). When there is a [2] consolidation of this operation, the group's existence is made possible since it is responsible for the group's activities costing.

Leme's (2015) theoretical contribution is the identification of Market Building Practices (in this work Structuring Practices), which are conducted by actors to assist in the establishment of market arrangements. When analyzing the market under construction of UTZ certification, it was identified that [1] the internal control of the construction of the market, [2] the construction of hybrid forums, [3] the construction of market devices to make other actors take actions, and [4] the construction of the traceability system are actions that help UTZ to form its operating market. However, Structuring Practices were also observed among other actors considered in this work, meaning that they also act to shape the market, participating in its construction.

Regarding the Management Unit, the determination of the [1] Strategic Orientation of the group influences the construction of the market through the group's scope, since from its strategy the Management Unit will indicate the geographical extension and the number of producers assisted, for example. The Management Unit also performs the [2] Adaptation of the standard to the local context, that is, it helps the assimilation of the standard's key concepts by the producers by using a simpler language then the one adopted by UTZ.

The Management Unit, like UTZ, builds important market devices such as [3] the Field Notebook, so that producers can provide their performance information, and which determines the direction of other Market Practices conducted by them; and the [4] Motivational Case aimed at convincing the producer to join the Institutional Program and thus take part of the group.

Considering the context of the producer, the [1] development of strategic partnerships by establishing commercial and institutional relations with other entities outside the cooperative or Management Unit is a relevant Structuring Practice to make the producer use the certification as a sales tool and allow transactions to occur, directing products of different qualities to different buyers, for example. Finally, the [2] assimilation of the motivation case is also considered a Structuring Practice because the entry point of the motivation case conveyed by the Management Unit is very specific to each producer, which also changes their perception about certification regarding its benefits and challenges.

In this way, the Market Practices carried out by UTZ identified by Leme (2015) reverberate in different ways in the Management Unit and the Certified Producers, changing their Market Practices. It appears that all the actors observed in the context of this research, each in their way, contribute to building the certification market, proposing new Market Practices as their behavior is altered by the practices conducted by UTZ certification (Table 4). 


\begin{tabular}{|c|c|c|c|}
\hline Practices & UTZ (Leme, 2015) & Management Unit & Producer \\
\hline \multirow{2}{*}{ Representational } & $\begin{array}{l}\text { Norms and rules of other } \\
\text { systems }\end{array}$ & $\begin{array}{l}\text { Centralization of } \\
\text { representation }\end{array}$ member & $\begin{array}{l}\text { Reassignment of property in } \\
\text { rural development }\end{array}$ \\
\hline & $\begin{array}{l}\text { UTZ philosophy and its } \\
\text { transformations }\end{array}$ & $\begin{array}{l}\text { Replacement of UTZ as a } \\
\text { representation of certification }\end{array}$ & $\begin{array}{l}\text { Aesthetical and functional } \\
\text { reframing }\end{array}$ \\
\hline \multirow{2}{*}{ Normative } & $\begin{array}{l}\text { New versions of the UTZ } \\
\text { Code }\end{array}$ & Provision of technicaladvice & $\begin{array}{l}\text { Implementation of the practices } \\
\text { demanded by UTZ }\end{array}$ \\
\hline & $\begin{array}{l}\text { Governance system/ } \\
\text { delibera tive committees }\end{array}$ & $\begin{array}{l}\text { Creation of the group's operation } \\
\text { and control rules }\end{array}$ & Filling in the field notebook. \\
\hline \multirow{2}{*}{ Exchanging } & $\begin{array}{l}\text { Price and premium } \\
\text { formation }\end{array}$ & $\begin{array}{l}\text { Consolidation of the barter } \\
\text { operation }\end{array}$ & $\begin{array}{l}\text { Development of sales strategies } \\
\text { and risk dilution }\end{array}$ \\
\hline & $\begin{array}{l}\text { Transparency practices in } \\
\text { transactions. }\end{array}$ & $\begin{array}{l}\text { Preparation of the institutional } \\
\text { program }\end{array}$ & $\begin{array}{l}\text { Use of the group's traceability } \\
\text { system }\end{array}$ \\
\hline \multirow{4}{*}{ Structuring } & $\begin{array}{l}\text { Internal control of market } \\
\text { construction }\end{array}$ & Strategic orientation of the group. & \multirow{2}{*}{$\begin{array}{l}\text { Development of strategic } \\
\text { partnerships }\end{array}$} \\
\hline & $\begin{array}{l}\text { Construction of hybrid } \\
\text { forums }\end{array}$ & $\begin{array}{l}\text { Adaptation of the standard to the } \\
\text { local context. }\end{array}$ & \\
\hline & Construction of devices. & Construction of the field notebook & \multirow{2}{*}{$\begin{array}{l}\text { Assimilation of the motivational } \\
\text { case. }\end{array}$} \\
\hline & $\begin{array}{l}\text { Construction of } \\
\text { electronic portal. }\end{array}$ & $\begin{array}{l}\text { Construction of the motivational } \\
\text { case. }\end{array}$ & \\
\hline
\end{tabular}

Table 4. Market practices observed in the study.

Source: The authors.

\subsection{Implementation of UTZ Market Practices in the productive context}

The Producers' reinterpretations (representation) alter UTZ's norms through its deliberative (normative) systems, which in turn alter the institutional program's value proposition and the barter operations (transaction) of the Management Unit. Another example is that when UTZ establishes price formation policies for the certified product (transaction), due to the centralization of the certification representation by the Management Unit (representation), discussions occur to decide how the group will behave with this financial aspect in terms of costing, which will influence the ability of producers to implement certification practices (normative). Below, an excerpt from one of the interviewees illustrates the above.

\footnotetext{
"These $\mathrm{R} \$ 10,00$ there (premium), according to them, is a bonus that the cooperative pays to encourage continuing with the plan, because I don't know, according to them, they are not able to sell the coffee as a certified coffee. So, these ten reais is the bonus that the cooperative pays just to keep the group functioning, that's what they gave me, becau se I've already questioned it several times." (Interviewee 09).
}

Thus, considering the theoretical aspects of CMS, it was demonstrated how the Market Practices conducted by UTZ influence other Market Practices of different actors inserted in the same observed market context (Table 2). This interaction between Market Practices of a different nature, that is, representation of actor A concerning the norms of actor B, for example, is observable from the Translation Chains, confirming the statements of Kjellberg and Helgesson (2007).

This concept is explained in the theoretical bases of the Actor-Network Theory to explore the concept of Inscription, which refers to how Market Practices are transported along and between the components of a sociotechnical arrangement (Latour, 1996). In the context of CMS, inscription is an observable trail that shows the transportation of a Market Practice of the same nature to the perspective of another actor. In this work, it was observed that inscriptions are observable traces of how the Market Practices of an actor were assimilated or dissociated by another actor in the organization, observation made possible due to the existence of Structuring Practices. It is worth 
noticing that this is not a hierarchy, but an ordering of a specific socio-technical process, that is, an interaction between actors.

Regarding the Representational Practices, the norms and rules of other systems and the UTZ Philosophy and its transformations are traceable when considering as inscriptions the establishment of the group certification scope, allowing producers to be certified with a system management, and a subjective base of values that indicates the 'generic' benefits of certification that one or more producers can identify as an ideal motivation for certification. These inscriptions help to understand why the Management Unit applies the Representational Practices here named 'Centralization of the UTZ representation' and 'Replacement of UTZ as a representation of the certification': the assimilation of the inscriptions channels the transformations of the market to carry out these Practices. An example can be seen below.

\begin{abstract}
"Ah, you know that, to produce it is not difficult, to produce it is not difficult, now to produce in the way it needs to be produced, with quality, it is difficult, because then you cannot use what you could use anyway today, no you can, if you are certified, you have to, you have a goal, you have to meet that goal there, defensive stuff, it's something that, for example, drill, drill is a train that gets in the way of certification, you can't use any product, you have to do it, work in the harvest, understand? The quality, I acquire the quality of the product." (Interviewee 08).
\end{abstract}

Using the same procedure, the Producers conduct as Representational Practices the 'aesthetic and functional resignification' based on the assimilation of the Management Unit as an institution and the values it promotes as part of a convincing action so that the producer accepts to be part of the group. In the same way, UTZ also assimilates these aesthetic and functional modifications in order to refine and update what is the representation of the certification for that given context, as shown in Figure 4. In addition, an excerpt from an interviewee can be associated with: "The more organized, the easier it is to follow, got it? So, the certification fit like a glove, it was exactly what I needed, in addition to organizing, I'm getting paid to organize and that's what I wanted to do even if I didn't have a certificate, understand?" (Interviewee 12).

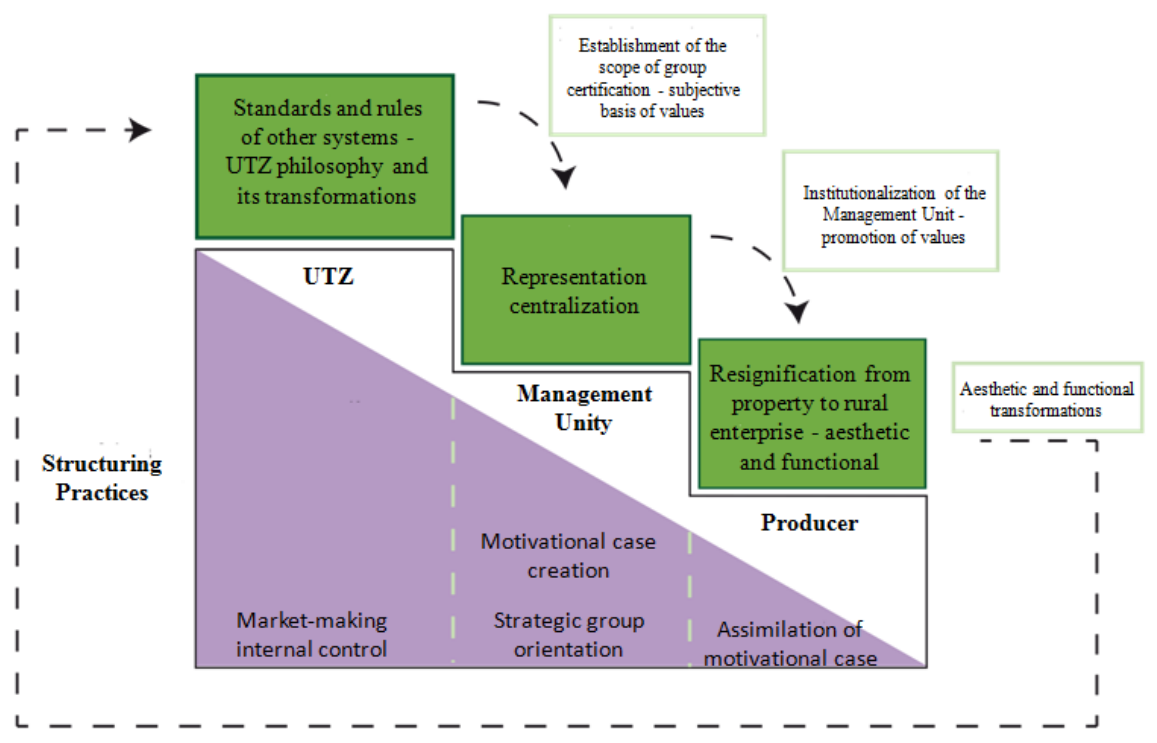

Figure 4. Inscriptions observed in the Representation Practices. Source: The authors.

Regarding the Normative Practices, starting from UTZ Practices of New versions of the UTZ Code and Governance and deliberation Systems, it is observed that when considering as inscriptions the exercise of influence on the premises of technical advice and the institution of rules, the assimilation by the Management Unit gives rise to the Normative Practices of 'providing \begin{tabular}{|l|l|l|l|l|l|}
\hline Rev. Gest. Soc. Ambient. & São Paulo (SP) & v.15 & p.01-21 & e02786 & 2021. \\
\hline
\end{tabular} 
technical advice' and 'creation of the rules of group operation' because the Normative Practices conducted by UTZ transfer responsibilities to the Management Unit, which responds to these responsibilities through the establishment of rules and premises for the implementation of the UTZ Standard criteria. For producers, their Normative Practices of 'implementing the practices demanded by UTZ' and 'filling in the field notebook' are observable when considering the systematization of the standard to the local context, to facilitate the assimilation of concepts, and the placement of the field notebook as a condition to remain in the group, as filling it out can be a timeconsuming and tiring activity, as narrated by the producers throughout the interview process. The notion of viability and the certification routine are assimilated by UTZ itself to propose new versions of its Code, as shown in Figure 5, which summarizes this interaction process.

Regarding Exchange Practices, UTZ conducts the 'formation of the price and premium' and 'transparency practices' and when observing the conceptual internalization of the price, premium and transparency, the premises on which the Management Unit bases the Creation of its institutional program are observed and consolidates its barter operation. From the perspective of the Producer, the sale and risk dilution strategies and the use of the group's traceability system are originated by making the certification group viable as a structured entity to operate such strategies, and by the Management Unit's value proposal for this Producer. Therefore, trends in the coffee macro-market and information shared by producers influence how UTZ positions its pricing, as shown in Figure 6. Furthermore, an excerpt from one of the interviewees can expand this scenario

\footnotetext{
"Yeah, because actually, this is something paid for by the cooperative, right? and when you have a certified coffee, I noticed, it is a vailable for you to negotiate even with other people, then you can even get it. I think, one thing the certification could try to help us with at this point, was trying to introduce other customers, I think, I don't know, the certification maybe, our name has somewhere on the website, where the customer who wants to buy certified coffee, he find these people here. [...] . Yeah... because actually this is a slow process, despite being since 2014, but I still don't feel able to offer my coffee in a more demanding market. Did you understand? [...] I know there is a market, that he, he wants to buy your product, but what does he demand?"(Interviewee 02).
}

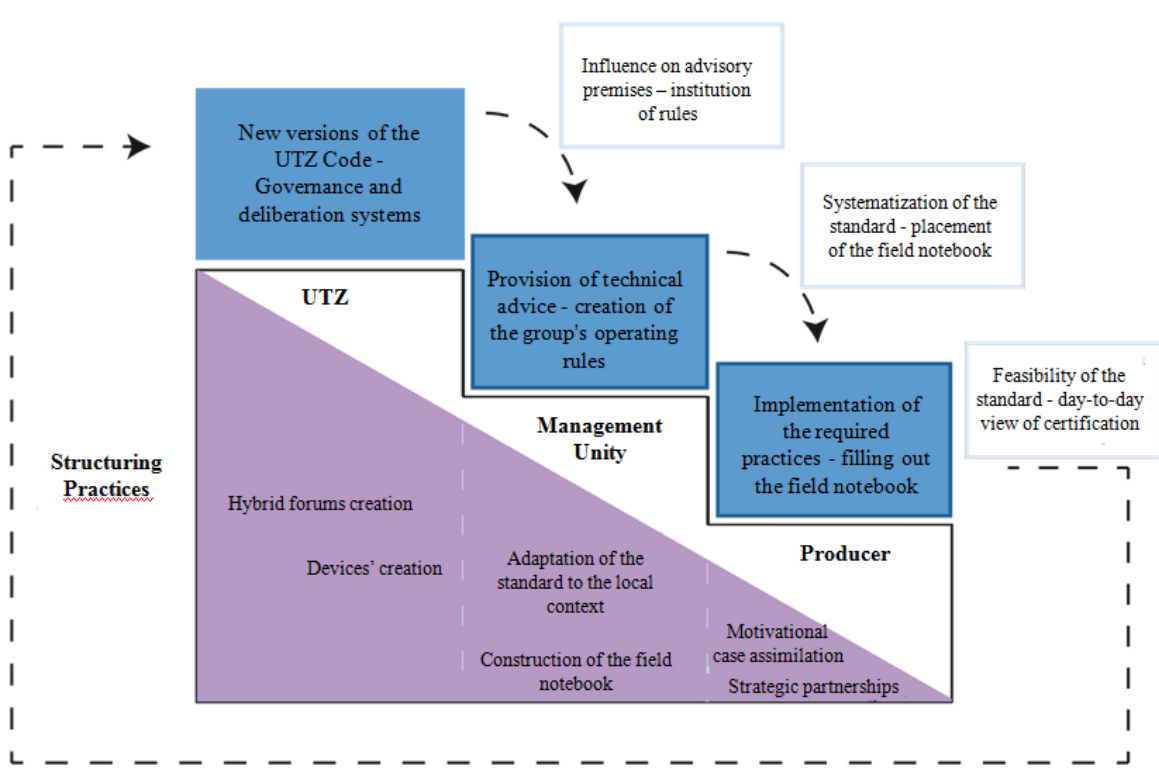

Figure 5. Inscriptions observed in the Normative Practices.

Source: The authors. 


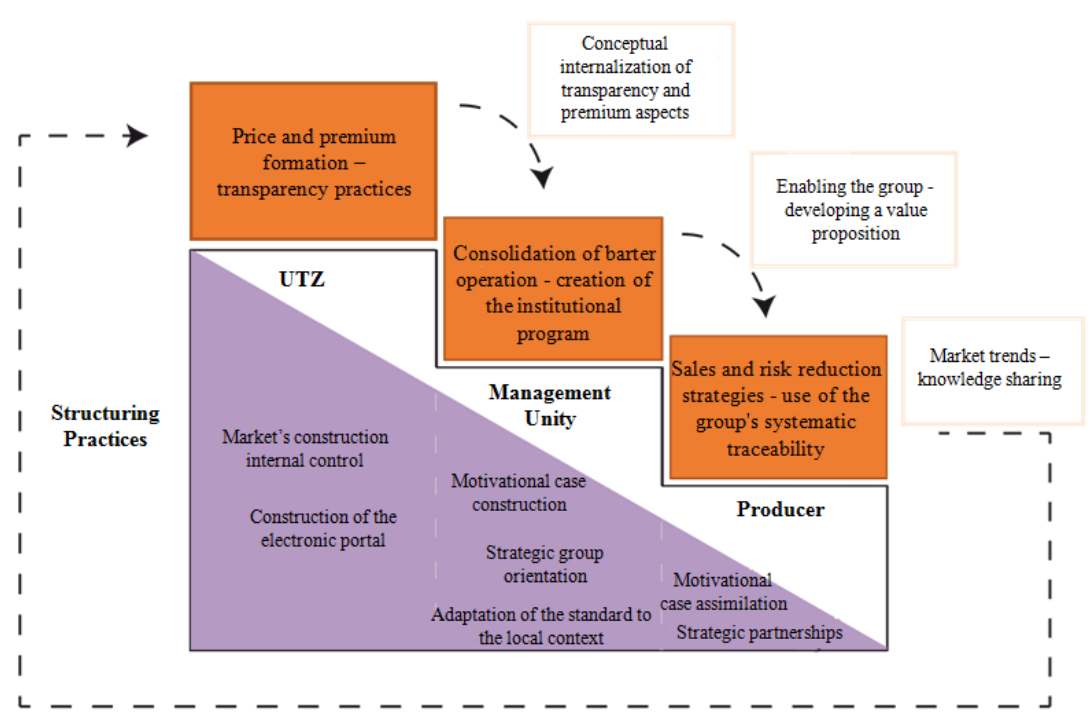

Figure 6. Inscriptions observed in the Exchange Practices.

Source: The authors.

A level of interaction between Market Practices of a different nature, represented by the Translation Chains, and a level of interaction between Market Practices of the same nature, represented by the Inscriptions, illustrate the influence of these Market Practices in the design of others. Figure 7 shows the interpretation model of CMS in this study.

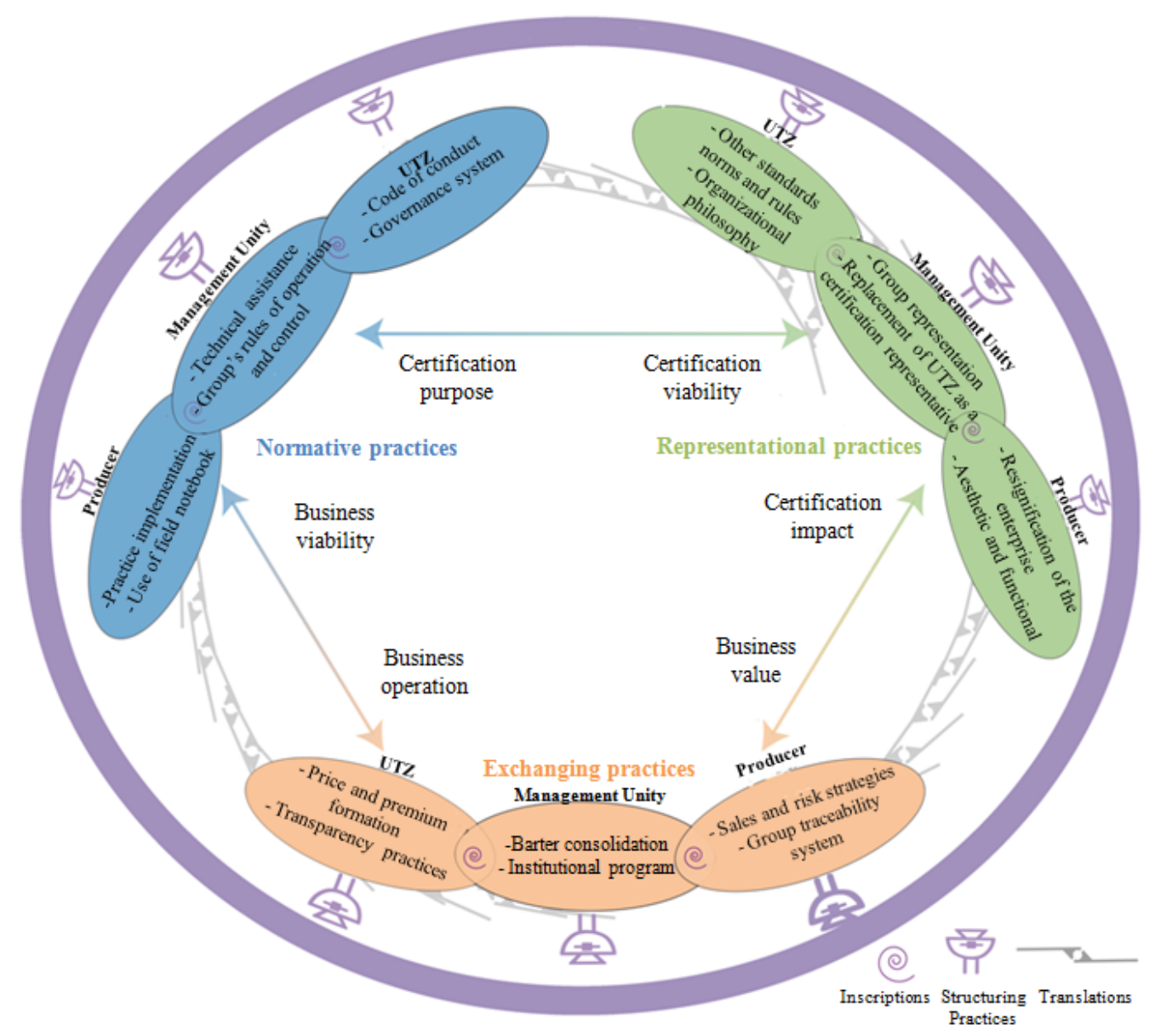

Figure 7. Interpretative model of Constructive Market Studies.

Source: The authors.

\begin{tabular}{|l|l|l|l|l|l|l|}
\hline Rev. Gest. Soc. Ambient. & São Paulo (SP) & v.15 & p.01-21 & e02786 & 2021. \\
\hline
\end{tabular} 
The Structuring Practices, in addition to helping in the construction of the market according to Leme (2015), have the important function of catalysts of these inscription processes, making them visible and giving dynamism to the market from the assimilation or dissociation of the Market Practices. In addition, actors perform Structuring Practices to strengthen or weaken coordination relations, supporting new Market Practices based on these new constituted relations.

\section{CONCLUDING REMARKS}

The purpose of this article was to show how the Market Practices conducted by UTZ are translated in the context of agricultural production and how they are implemented. Both UTZ and the other actors observed in this study conduct Market Practices and Structuring Practices to shape the market in which they are inserted. Each in its way, the actors act to ensure their interests in the market in consequence to the actions of other actors in a given order.

The CMS are adequate models to explain the formation of the markets as performative elements, especially under the perspective of practical functioning, allowing the mapping of the interactions between actors, Market Devices and Practices, representing the products of these interactions to position the function of each of these elements in the constructive and changing context of the markets.

However, it was identified an interpretive gap in the CMS on how to identify this same interaction in Market Practices of the same nature, that is, Exchange Practices of actor A with those Exchange Practices of actor B, for example. There is a level of interaction between Market Practices not foreseen in the initial model of CMS, where the practical arrangements for market operation and the means of assimilation of Market Practices by other actors are not considered from a dynamic perspective. It was observed that Market Practices of the same nature are transported to the perspectives of other actors contained in an order, which may or may not replicate these Market Practices or as was mainly observed, create new Market Practices. When considering the inscriptions in this context, it was possible to use them as a trail to understand how this transportation took place.

The results of this transportation reveal a means by which actors can also create new Market Practices, since from the reaction of other actors, it is possible to refine, review, improve or even reconstruct Market Practices implemented in the Market. The dynamism that is seen between the Representational, Normalizing and Exchange Market Practices, is also observed among the market regulations when considering a type of Market Practice in isolation.

Translation Chains make it possible to identify transformations between Market Practices of a different nature, while Inscriptions help us to observe the transport of Market Practices of the same nature throughout the order considered. It was suggested that the Inscription process is crucial for observing changes in Market Practices, and framings and overflows in the Market Arrangement.

Considering the aspect of the inscriptions, it was possible to expand the theoretical model of CMS, in addition to demonstrating Market Practices conducted by other actors from the Market Practices conducted by UTZ whose interactions were demonstrated through the Translation Chain and Inscription.

Therefore, the social contribution of this work is to highlight how the impacts of UTZ certification change the lives of small rural producers through the implementation of sustainable practices, promoting positive transformations in their properties.

As managerial contributions, we highlight the observation of the relationship between Certification, Management Unit and Producer from an organizational perspective of a certification group. As a theoretical contribution, this article expanded the systematization of Inscriptions in the process of assimilating Market Practices of the same nature within the context of Constructivist Market Studies. It is noteworthy that the concept of registration is still little explored in the CMS 
and it is crucial for its understanding, as it concerns the traces of Translations in the market, something important to understand the market's performativity.

However, the scope of this work has limitations. Among them, there is the fact that the perspective of the auditing company was not considered within the certification process, since the work had limitations related to the confidentiality of the certification process, which, due to reasons arising from the Certification Protocol, could not be exploited or surpassed.

As suggestions for future research, we recommend to observe the context of coffee production through other theoretical lenses, such as Agricultural Marketing, to analyze how the communication of the impact of certification takes place in the market. Another work suggestion is to better understand the Market Arrangements formed within the production axis of the certification chain, mainly from the perspective of the interaction of the Farmer with other agents in the supply chain, not necessarily the cooperative - but other buyers and coffee shops, for example.

\section{REFERENCES}

Andrade, J. A. (2004). Actor-network theory (ANT): uma tradução para compreendero relacional e o estrutural nas redes interorganizacionais? Cadernos EBAPE, 2 (2), 1-14.

Araújo, L., Kjellberg, H., \& Spencer, R. (2008). Market practices and forms: introduction to the special issue. Marketing Theory, 8 (1), 5-14.

Bardin, L. (2011). Análise de Conteúdo. São Paulo: Edições 70.

Bennett, E. (2017). Who Governs Socially-Oriented Voluntary Sustainability Standards? Not the Producers of Certified Products. World Development (91), 53-69.

Çaliskan, K. (2007). Price as a market device: cotton trading in Izmir Mercantile Exchange. The Sociological Review, 241-261.

Çaliskan, K., \& Callon, M. (2010). Economization, part 2: a research programme for the study of markets. Economy and Society , 39 (1), 1-32.

Callon, M. (1998). An Essay on Framing and Overflowing: Economic Externalities Revisited by Sociology. The Sociological Review , 46 (S1), 244-269.

Callon, M. (2015). Revisiting marketization: from interface-markets to market-agencements. Consumption Markets \& Culture, 1-21.

Callon, M. (1986). The Sociology of an Actor-Network: The Case of the Electric Vehicle. In: M. Callon, J. Law, \& A. Rip, Mapping the dynamics of science and technology. (1 $\left.1^{\mathrm{a}} \mathrm{ed} ., \mathrm{pp} .19-34\right)$. Londres: Palgrave Macmillan.

Callon, M., \& Muniesa, F. (2005). Economic Markets as Calculative Collective Devices. Organization Studies , 26 (8), 1229-1250.

Cochoy, F. (2008). Calculation, qualculation, calqulation: shopping cart arithmetic, equipped cognition and the clustered consumer. Marketing Theory, 8 (1), 14-44.

Daviron, B., \& Ponte, S. (2006). The Coffee Paradox: Global markets, commodity trade and the elusive promise of development. Londres: Zen Books.

Formentini, M., \& Taticchi, P. (2016). Corporate sustainability approaches and governance mechanisms in sustainable supply chain management. Journal of Cleaner Production (112), 19201933.

Geiger, S., \& Kjellberg, H. (2021). Market mash ups: The process of combinatorial market innovation. Journal of Business Research, 124, 445-457. 
Guimarães, E. R., Leme, P. H., de Rezende, D. C., Pereira, S. P., \& do Santos, A. C. (2018). The brand new Brazilian specialty coffee market. Journal of Food Products Marketing , 1-23.

Hagberg, J., \& Fuentes, C. (2018). Retail formations: tracing the fluid forms of an online retailer. Consumption Markets \& Culture, 21(5), 423-444.

Hagberg, J., Kjellberg, H., \& Cochoy, F. (2020). The Role of Market Devices for Price and Loyalty Strategies in 20th Century US Grocery Stores. Journal of Macromarketing, 40(2), 201-220.

Instituto Brasileiro de Geografia e Estatística. (2006). Censo Agropecuário. Rio de Janeiro: IBGE.

International Coffee Organization. (2021). World coffee production. (ICO, Editor) http://www.ico.org/monthly_coffee_trade_stats.asp

Janssen, F., \& van Berkel, B. (2014). Making Philosophy of Science Education Practical for Science Teachers. Science \& Education, 24 (3), 229-258.

Kjellberg, H., Hagberg, J., \& Cochoy, F. (2019). Thinking Market Infrastructure: Barcode Scanning in the US Grocery Retail Sector, 1967-2010. In Thinking infrastructures. Emerald Publishing Limited.

Kjellberg, H., \& Helgesson, C.-F. (2006). Multiple versions of markets: Multiplicity and performativity in market practice. Industrial Marketing Management, 35, 839-855.

Kjellberg, H., \& Helgesson, C.-F. (2007). On the nature of the markets and their practices. Marketing Theory, 7 (2), 137-162.

Kjellberg, H., \& Liljenberg, A. (2003). Marketing on trial-practices and principles in the case of SAS'EuroBonus program. In Stockholm School of Economics, 19th Annual IMP-conference, University of Lugano (pp. 4-6).

Kolk, A. (2011). Mainstreaming Sustainable Coffee. Sustainable Development , 1-14.

Latour, B. (1994). Jamais fomos modernos: ensaios de antropologia simétrica (1 ${ }^{\text {a }}$ ed.). São Paulo: Editora 34.

Latour, B. (1996). On actor-network theory: A few clarifications. Soziale Welt , 47 (4), 369-381.

Leme, P. H. (2015). A construção do mercado de cafés certificados e sustentáveis da UTZ Certified no Brasil: As práticas e os arranjos de mercado. 273p. Tese (Doutorado em Administração). Programa de Pós-Graduação em Administração, Universidade Federal de Lavras, Lavras, MG, Brasil.

Leme, P. H., \& Rezende, D. C. (2018). A construção de mercados sob a perspectiva da Teoria AtorRede e dos Estudos de Mercado Construtivistas (EMC). RIMAR - Revista Interdisciplinar de Marketing , 8 (2), 133-151.

Leme, P. H., \& Rezende, D. C. (2016). Práticas de Mercado e a Construção de Mercados: Análise dos Cafés Certificados e Sustentáveis da Utz Certified no Brasil. Encontro Nacional da Associação de Pesquisa e Pós Graduação em Administração , 1-16.

MacGregor, F., Ramasar, V., \& Nicholas, K. A. (2017). Problems with firm-led voluntary sustainability schemes: the case of direct trade coffee. Sustainability, 9(4), 1-25.

Mason, K., Kjellberg, H., \& Hagberg, J. (2015). Exploring the performativity of marketing: theories, practices and devices. Journal of Marketing Management, 31 (1-2), 1-15.

Miranda, P. d. (2009). A Teoria Ator-Rede como Framework Teórico para o Estudo dos Processos de Participação Democrática Apoiados por Tecnologia da Informação no Brasil. II Encontro de Administração da Informação , 1-15. 
Muniesa, F., Millo, Y., \& Callon, M. (2007). An introduction to market devices. The sociological review , 55, 1-12.

Nassar, A. M. (2003). Certificação no agribusiness. In: Zylberstajn, D.; Scare, R. (Org). Gestão da qualidade no Agribusiness. Editora Atlas, 44.

Neyland, D., Ehrenstein, V., \& Milyaeva, S. (2019). On the difficulties of addressing collective concerns through markets: from market devices to accountability devices. Economy and society, 48(2), 243-267.

Nøjgaard, M., \& Bajde, D. (2020). Comparison and cross-pollination of two fields of market systems studies. Consumption Markets and Culture, 0(0), 1-22. https://doi.org/10.1080/10253866.2020.1713112

Reinecke, J., Manning, S., \& Von Hagen, O. (2012). The Emergence of a Standards Market: Multiplicity of Sustainability Standards in the Global Coffee Industry. Organization Studies , 33 (5), 791-814.

Souza, C. E. (2019). Práticas estruturantes e de mercado na construção do impacto em sustentabilidade: os processos de translação e inscrição na produção de café certificado no contexto sul-mineiro. 218p. Dissertação (Mestrado em Administração). Programa de Pós-Graduação em Administração, Universid ade Federal de Lavras, Lavras, MG, Brasil.

Triviños, A. N. (1987). Introdução à pesquisa em ciências sociais: a pesquisa qualitativa em educação. São Paulo: Atlas.

UTZ. (2016a). Annual Report. Source: UTZ: https://utz.org/wp-content/uploads/2017/05/UTZAnnual-report-2016.pdf

UTZ. (2015). Código de Conduta Núcleo 1.1 para certificação em Grupo e Multi-Grupo. Acesso em 21 de Outubro de 2018, disponível em Resource Library: https://utz.org/wpcontent/themes/utz/download-attachment.php?post_id=3673

UTZ. (2018). Protocolo de Certificação 4.2. Source: UTZ Resource Library: https://utz.org/wpcontent/themes/utz/download-attachment.php?post_id=16306

UTZ. (2017). Sector Change. Source: UTZ: https://utz.org/what-we-offer/sector-change/

UTZ. (2016b). UTZ: What's in a name? Source: UTZ: https://utz.org/better-businesshub/marketing-sustainable-products/utz-whats-in-a-name/

Yin, R. (2001). Estudo de caso: planejamento e métodos (2ºd.). (D. Grassi, Trad.) Porto Alegre: Bookman. 